\title{
Promotion of Berseem Variety Wardan through Frontline Demonstrations in Unnao District of Uttar Pradesh, India
}

\author{
Sunil Singh $^{1 *}$, A.K. Singh ${ }^{1}$, Archana Singh ${ }^{1}$, Ratna Sahay ${ }^{1}$, Dheeraj Kumar Tiwari ${ }^{1}$, \\ R.C. Maurya ${ }^{1}$, Vikash Chandra ${ }^{1}$ and U.S. Gautam ${ }^{2}$ \\ ${ }^{1}$ ICAR- Krishi Vigyan Kendra, Unnao - 229881 (Uttar Pradesh), India \\ ${ }^{2}$ ICAR-ATARI, Zone-III, Kanpur- 208002 (Uttar Pradesh), India \\ *Corresponding author
}

\section{A B S T R A C T}

\section{Keywords \\ Berseem fodder, Extension gap, \\ Economic, Frontline demonstration, Technology gap \\ Article Info \\ Accepted: \\ 12 July 2018 \\ Available Online: \\ 10 August 2018}

\begin{abstract}
Berseem is a major fodder crop of Uttar Pradesh as well as the country and plays a major role in augmenting the income of small and marginal farmers of Unnao district of Uttar Pradesh. One of the major constraints of traditional Berseem cultivation is low productivity due to non-adoption of recommended package of practices and improved varieties. To overcome this anomaly Krishi Vigyan Kendra, Unnao were conducted frontline demonstrations in farmers' fields at different locations in the district with high yielding and no. of cutting variety Wardan and applying scientific practices in cultivation through broadcasting method. The Berseem productivity and economic returns under improved technologies were calculated and compared with the prevailing farmers' practice. Results revealed that Wardan variety under improved practices recorded higher yield of $17.09 \%, 19.98 \%$ and $25.83 \%$ during $2013-14,2014-15$ and $2015-16$ and the recommended practice gave higher net returns of Rs 26100,28500 and 31700 per ha and $\mathrm{B}: \mathrm{C}$ ratio of $2.16: 1,2.34: 1$ and $2.60: 1$, respectively as compared to farmers practice.
\end{abstract}

\section{Introduction}

Berseem (Trifolium alexandrinum) is one of the most important winter forage legumes in India, Pakistan, Turkey, Egypt and countries of Mediterranean region. The crop is reported to be highly self-incompatible in its place of origin but in India it is believed to be self fertile. However, in a recent report, the crop has shown wide diversity for self fertility and population with self compatible and self pollinating, self compatible requiring tripping,
Self incompatible types with broad genetic base and self incompatible types with narrow genetic base. In India, it occupies $2 \mathrm{M}$ ha. The merit of the crop lies in its multicut nature (46 cuts), long duration of green fodder availability (November to April), high green fodder yield ( $85 \mathrm{t} / \mathrm{ha}$ ), good forage quality (20\% crude protein), and digestibility (up to $65 \%$ ) and high palatability (Anonyms 2009). The yield components in berseem varieties and number of tillers per square meter were major factors related to fodder yield (Beri and 
Sahoo, 1985 and 1986) and as well as the cutting intervals of 20 and 25 days significantly decreased the incidence of root rot disease in berseem fodder and increased the green fodder yield (Munir, 2001). The present study was conducted to promotion of high yielding green fodder and multicut variety of berseem.

\section{Material and Methods}

Frontline demonstrations (FLDs) in Berseem were conducted during 2013-14, 2014-15 and 2015-16 by Krishi Vigyan Kendra, Unnao at the farmers' fields in different locations of the district. A total of 30 demonstrations in 6 ha area were conducted in the selected villages. The improved variety Wardan was procured from Indian Grassland and Fodder Research Institute, Jhansi (Uttar Pradesh) for demonstration purpose. In case of local check plots, existing practice of broadcasting was followed by the farmers. The whole package approach demonstrated to farmers through FLD trials included components such as improved variety, broadcasting method sowing, recommended seed rate, seed treatment, weed and water management, fertilizers and plant protection measures (Table 1). In the demonstration plots critical inputs in the form of improved seed of Wardan variety and balanced fertilizers were provided to the farmers. The farmers involved in demonstrations were facilitated by KVK scientists in performing proper field operations like; timely sowing, cutting time and disease diagnosis. During this period extension activities like field days, farmers' trainings, diagnostic visits, etc. were undertaken which benefitted the farmers. Data on crop yield were recorded by per square meter observation method randomly from 3 to 4 places from an FLD plot. The yield data were collected from both the demonstrations and farmers' fields and analyzed using simple statistical tools. The technology gap, extension gap and technology index (Samui $e t$ al., 2000) were calculated using the following equation:

Technological gap: Potential yield demonstration yield

$>$ Extension gap: Demonstration yield yield under farmer practice

$>$ Technology index (\%): (Potential yield demonstration yield/potential yield) X 100

\section{Results and Discussion}

The fodder yield of Berseem recorded under demonstration was 597.2, 621.5 and $668.2 \mathrm{q}$ ha- ${ }^{1}$ during 2013-14, 2014-15 and 2015-16, respectively (Table 2). The yield enhancement due to the improved practices was to the tune of $17.09,19.98$ and 25.83 per cent over farmers' practice. Moreover, the number of cutting of fodder under demonstration was recorded 3, 4 and 4 times over the farmers field. Yield enhancement in Berseem and other fodder crops under frontline demonstration has amply been documented by Haque (2000) and Tiwari and Saxena (2001). The Extension gap of 87.2, 103.54 and $137.2 \mathrm{q} \mathrm{ha}^{-}{ }^{1}$ was observed during 2013-14, 2014-15 and 2015-16, respectively. The Extension gap emphasized the need to bring awareness among the farmers for adoption of improved varieties and production technologies and to revert the trend of wide extension gap. Results also revealed that the technological gap between the improved technology (Demonstration) and farmers' practice in tune of $102.8,78.46$ and 31.8 q ha- ${ }^{1}$ during 2013-14, 2014-15 and 2015-16, respectively. The technology gap observed may be attributed to difference in soil fertility status and agricultural practices and may be overcome by adopting efficient management practices. The technology index indicates the feasibility of the evolved technology at the farmers' fields. Lower the values of technology index more is the feasibility of the technology demonstrated (Chauhan, 2011). 
Table.1 Demonstration and Farmers practices of Berseem under FLD for varietal evaluation

\begin{tabular}{|r|c|c|c|c|}
\hline Sl. No. & Technology & $\begin{array}{c}\text { Improved practices } \\
\text { under flat sowing }\end{array}$ & Farmers practice & GAP (\%) \\
\hline $\mathbf{1}$ & Variety & Wardan & Non-descript & 100 \\
\hline $\mathbf{2}$ & Land preparation & $\begin{array}{c}\text { Ploughing, Harrowing } \\
\text { and pudling }\end{array}$ & $\begin{array}{c}\text { Ploughing, Harrowing } \\
\text { and pudling }\end{array}$ & 50 \\
\hline $\mathbf{3}$ & Seed rate & $25 \mathrm{~kg}(\mathrm{Ha})$ & $40 \mathrm{Kg}(\mathrm{Ha})$ & High seed rate \\
\hline $\mathbf{4}$ & Seed treatment & Thiarum & No application & 100 \\
\hline $\mathbf{5}$ & Sowing method & Broadcasting & Broadcasting & 50 \\
\hline $\mathbf{7}$ & Fertilizer dose & $80-40-20(\mathrm{~N}-\mathrm{P}-\mathrm{K})$ & $\begin{array}{c}\text { Indiscriminate } \\
\text { application }\end{array}$ & 100 \\
\hline $\mathbf{8}$ & Plant protection & IPM & $\begin{array}{c}\text { Indiscriminate } \\
\text { application }\end{array}$ & 100 \\
\hline
\end{tabular}

Table.2 Yield performances of Wardan under demonstration

\begin{tabular}{|c|c|c|c|c|c|c|c|}
\hline Years & $\begin{array}{c}\text { No. of } \\
\text { Demonstrations }\end{array}$ & $\begin{array}{c}\text { Area } \\
\text { (ha) }\end{array}$ & \multicolumn{2}{|c|}{$\begin{array}{c}\text { Fodder Yield } \\
\left(\mathrm{q} \mathrm{ha}^{-1}\right)\end{array}$} & $\begin{array}{c}\text { Increased } \\
\%\end{array}$ & \multicolumn{2}{|c|}{ No of cutting } \\
\cline { 3 - 6 } & & & $\begin{array}{c}\text { Demo } \\
\text { Farmer's } \\
\text { practice }\end{array}$ & & Demonstration & $\begin{array}{c}\text { Farmer } \\
\text { practice }\end{array}$ \\
\hline $\mathbf{2 0 1 3 - 1 4}$ & 10 & 2.0 & 597.20 & 510 & 17.09 & 3 & 2 \\
\hline $\mathbf{2 0 1 4 - 1 5}$ & 10 & 2.0 & 621.54 & 518 & 19.98 & 4 & 2 \\
\hline $\mathbf{2 0 1 5 - 1 6}$ & 10 & 2.0 & 668.20 & 531 & 25.83 & 4 & 3 \\
\hline
\end{tabular}

Table.3 Comparative economics of Berseem fodder cultivation between demonstration and farmers' practice

\begin{tabular}{|c|c|c|c|c|c|c|c|c|}
\hline \multirow{2}{*}{ Years } & \multicolumn{3}{|c|}{ Economics of demonstration (Rs./ha) } & \multicolumn{4}{c|}{$\begin{array}{c}\text { Economics of Farmer practice } \\
\text { (Rs./ha) }\end{array}$} \\
\cline { 2 - 10 } & Gross & $\begin{array}{c}\text { Gross } \\
\text { Cost }\end{array}$ & $\begin{array}{c}\text { Net } \\
\text { Return }\end{array}$ & $\begin{array}{c}\text { BCR } \\
\text { Return }\end{array}$ & $\begin{array}{c}\text { Gross } \\
\text { (R/C) }\end{array}$ & $\begin{array}{c}\text { Gross } \\
\text { Return }\end{array}$ & $\begin{array}{c}\text { Net } \\
\text { Return }\end{array}$ & $\begin{array}{c}\text { BCR } \\
\text { (R/C) }\end{array}$ \\
\hline $\mathbf{2 0 1 3 - 1 4}$ & 22500 & 48600 & 26100 & $2.16: 1$ & 18990 & 38800 & 19810 & $2.04: 1$ \\
\hline $\mathbf{2 0 1 4 - 1 5}$ & 21200 & 49700 & 28500 & $2.34: 1$ & 19995 & 41900 & 21905 & $2.09: 1$ \\
\hline $\mathbf{2 0 1 5}-16$ & 19500 & 51250 & 31750 & $2.60: 1$ & 18265 & 41560 & 23295 & $2.30: 1$ \\
\hline
\end{tabular}

Table.4 Technology gap, extension gap and technology index in Berseem (var. Wardan) under FLDs

\begin{tabular}{|c|c|c|c|}
\hline Year & $\begin{array}{c}\text { Technology gap } \\
\left(\mathrm{q} \mathrm{ha}^{-1}\right)\end{array}$ & $\begin{array}{c}\text { Extension gap } \\
\left(\mathrm{q} \mathrm{ha}^{-1}\right)\end{array}$ & $\begin{array}{c}\text { Technology index } \\
(\%)\end{array}$ \\
\hline $\mathbf{2 0 1 3 - 1 4}$ & 102.80 & 87.20 & 14.68 \\
\hline $\mathbf{2 0 1 4 - 1 5}$ & 78.46 & 103.54 & 11.20 \\
\hline $\mathbf{2 0 1 5}-16$ & 31.80 & 137.20 & 4.54 \\
\hline
\end{tabular}




\section{Mean \\ 71.02 \\ 109.31 \\ 10.14}

Figure.1 Technology gap, extension gap and technology index in Berseem (var. Wardan) under various FLDs

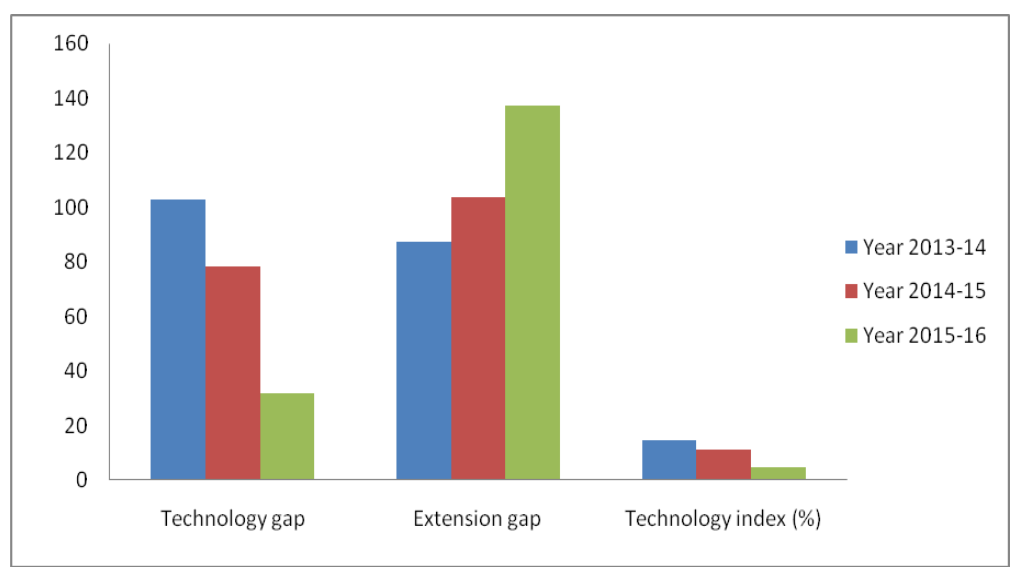

The technology index in the present study was $14.68,11.20$ and 4.54 per cent showing the efficacy of good performance of technical interventions. The reduction in the technology index from 14.68 per cent in the first year to 4.54 per cent in the third year exhibited the feasibility of the technology demonstrated (Table 4). The data on economics of the improved technology indicate that the cost of production in FLD was higher than that of the local practice (Table 3 ).

The input and output prices of the commodities prevailing during the study were taken into account for calculating the net returns and $\mathrm{B}: \mathrm{C}$ ratio. A higher net return of Rs 26100, 28500 and 31750 per ha was recorded during both the three years as compared to Rs 19810, 21905 and 23295 achieved as net returns in the farmers' practice. The benefit-cost ratio of Berseem fodder cultivation with wardan variety under improved cultivation practices was 2.16, 2.34 and 2.60 during both the three years as compared to $2.04,2.09$ and 2.30 under farmers' practice. This may be due to higher yield obtained under improved technologies and proved variety as compared to farmer's practice. The results were agreement with Tiwari and Saxena (2001).
In conclusion the fodder yield potential of Berseem cultivation increased to a great extent by conducting frontline demonstrations of the proven technologies. This substantially increased the income as well as rescue scarcity of green fodder for livestock farming. This method gained a momentum in upscaling the Berseem fodder productivity, which created a positive impact on livestock farming.

\section{Acknowledgement}

Authors thankful to ICAR- Krishi Vigyan Kendra, Unnao (UP) for providing necessary research facilities for conducting front line demonstration (FLD). Authors sincerely acknowledged ICAR-ATARI, Zone-III, Kanpur (UP) for providing financial supports.

\section{References}

Anonyms 2009. Descriptors for Tropical Forage Legume - Egyptian clover/Berseem Trifolium alexandrinum $L$., IGFRI, Jhansi.

Beri, S.M. and Sohoo, M.S. 1985. Performance of BL-1 variety of Berseem (Trifolium alexandrinum). 
Journal of Agricultural Research, 22(3): 598-599.

Beri, S.M. and Sohoo, M.S. 1986. Analysis of yield components in berseem, Journal of Agricultural Research, 23(4): 244247.

Munir, A.C. 2001. Cultural control of berseem root rot, Journal of Agricultural Research, 39(1): 45-49.

Samui, S.K., Mitra, S., Roy, D.K., Mandal, A.K. and Saha, D. 2000. Evaluation of frontline demonstration on groundnut. Journal of the Indian Society of Coastal Agricultural Research, 18(2): 180-183.
Haque, M.S. 2000. Impact of compact block demonstration on increase in productivity of rice. Maharashtra Journal of Extension Education, 19(1): 22-27.

Tiwari, K.B. and Saxena, A. 2001. Economic analysis of FLD of oilseeds in Chindwara. Bharatiya Krishi Anusandhan Patrika, 16 (3-4): 185189.

Chauhan, N.M. 2011. Impact and yield fissure inspection of gram through trainings and FLDs by KVK Tapi in Gujarat. Indian Journal of Agricultural Research and Extension, 4: 12-15.

\section{How to cite this article:}

Sunil Singh, A.K. Singh, Archana Singh, Ratna Sahay, Dheeraj Kumar Tiwari, R.C. Maurya, Vikash Chandra and Gautam, U.S. 2018. Promotion of Berseem Variety Wardan through Frontline Demonstrations in Unnao District of Uttar Pradesh, India. Int.J.Curr.Microbiol.App.Sci. 7(08): 1898-1902. doi: https://doi.org/10.20546/ijcmas.2018.708.218 